\title{
Поеднані ушкодження нервових та сухожилково-м'язових структур на передпліччі, що супроводжуються їх значними дефектами: роль вимушеної транспозиції м'язів у відновленні основних функцій кисті
}

\begin{abstract}
Мета роботи: оцінити ефективність “вимушених” транспозицій при ушкодженнях сухожилково-м’язових та нервових структур на відновлення основних захватів кисті.

Матеріали і методи. Проведено ретроспективний аналіз результатів реконструктивних втручань у 9 пацієнтів (6 чоловіків та 3 жінки) віком від 9 до 70 років (середній вік 36,4 року) із наслідками проксимальних поєднаних ушкоджень довгих нервів та сухожилково-м'язового апарату передньої поверхні передпліччя. Травма сухожилково-м'язового апарату була поєднана із ушкодженням в 4 випадках серединного нерва, в 4 випадках - серединного та ліктьового нервів, в одному випадку серединного нерва та поверхневої гілки променевого нерва. Термін, в який проводились реконструктивні втручання, складав у середньому 5 місяців (від 2 до 11 місяців) після травми. У 6 пацієнтів хірургічна реконструкція нервів полягала у виконанні автологічної пластики, у 2 пацієнтів - невролізу, в одного пацієнта - шва нерва. У 5 випадках “вимушена” транспозиція була виконана з метою відновлення незалежної функції довгого згинача 1 пальця, у 6 випадках - незалежної функції глибоких згиначів 2-3 пальців. Відновлення неврологічних функцій оцінювали за MRC Scale, класифікацією за Seddon, відновленням 4 захватів кисті, власною оцінкою відновлених функцій за Brief Michigan Hand Questionnaire.

Результати досліджень та їх обговорення. У всіх 4 пацієнтів із ушкодженням лише серединного нерва відновлення чутливості становило в середньому 3,75 за Seddon. У 4 пацієнтів із ушкодженням серединного та ліктьового нервів відновлення чутливості становило в середньому 3 та 2 за Seddon відповідно. Неефективне відновлення протиставлення першого пальця в 2 пацієнтів скореговано транспозицією за Bunnel. У 4 пацієнтів із ушкодженням серединного та ліктьового нервів ми спостерігали незадовільне відновлення “внутрішніх” м’язів кисті. У 5 пацієнтів “вимушені” транспозиції відновили незалежну функцію довгого згинача 1 пальця, у 6 пацієнтів - незалежну функцію глибоких згиначів 2-3 пальців. У 9 пацієнтів комплексна хірургічна реконструкція відновила функцію поперечного долонного, діагонального долонного та щипкового захватів. У 4 пацієнтів (44 \%) не досягнуто відновлення ключового захвату, у зв'язку із незадовільним відновленням “внутрішніх” м'язів кисті (ліктьовий нерв). Середня власна оцінка функції кисті за МBHQ відповідала задовільній у 9 пацієнтів - 70,12 балів в середньому (від 43,75 до 89,6).
\end{abstract}

Ключові слова: ушкодження; передпліччя; сухожилки; м’язи; транспозиція сухожилків; серединний нерв; ліктьовий нерв; автологічна пластика.

Постановка проблеми і аналіз останніх досліджень та публікацій. Ушкодження периферичних нервів (ПН) верхньої кінцівки являє собою одну із найголовніших причин стійкої втрати працездатності [1]. Ізольовані ушкодження ПН у структурі травми кінцівок займають відносно незначний відсоток [1]. Закрита травма кінцівки (в результаті падіння, травми тупим об’єктом) найчастіше супроводжується поєднанням ушкодження ПН із ушкодженням кісткових структур та, навпаки, при відкритих ушкодженнях кінцівок у структурі травми переважає поєднане ушкодження ПН, магістральних судин, сухожилковом'язового апарату [2, 3]. Загалом ушкодження ПН на передпліччі можна грубо розподілити на проксимальні та дистальні: проксимальні ушкодження $є$ більш прогностично несприятливими у контексті відновлення як чутливості, так і внутрішніх м’язів кисті [4]. Основною причиною таких тверджень $є$ значно більша відстань, яку мають подолати аксони, що регенерують, від зони ушкодження ПН до кінцевого органа-мішені [4].
Ще однією значущою характеристикою проксимальних ушкоджень передпліччя є втягнення в патологічний травматичний процес великої кількості власне м'язів, що частіше всього призводить до значного поглиблення рухового дефіциту [4]. Ушкодження м'язів характеризуються втратою їх здатності до видовження та скорочення [5, 6, 7]. Невеликі розриви м'язового черевця (зумовленого тупою закритою травмою) в більшості випадків вимагають лише консервативного лікування - загоєння шляхом “рубцювання” [6, 7]. Основним показом до хірургічного відновлення цілісності м'язів $€$ повний анатомічний перерив чи розриви більше 50 \% поперечного січення червця м'яза внаслідок відкритого чи закритого ушкодження [5, 6, 7]. Хiрургічне відновлення цілісності м'яза $є$ технічно надскладним процесом $[7,8]$, а основною вимогою до хірургічного відновлення цілісності м'яза залишається уникнення надлишкової резекції черевця під час хірургічної обробки [7]. М’яз, котрий втратив дистальну точку фіксації, протягом перших 7-10 днів значно вкорочується та втрачає ампліту- 
ду екскурсії, відповідно, хірургічна реконструкція пов'язана із високим ризиком розвитку повторних розривів у зоні анастомозування $[8,9,10]$.

Альтернативною методикою відновлення цілісності черевця м'яза шляхом прямого зшивання $€$ використання методики тенопластики за Pulvertaft iз використанням автологічних сухожилкових трансплантатів [10]. Основним недоліком даної техніки є необхідність використання донорських сухожилків та висока ймовірність ішемічної загибелі донора [10].

Навіть за умов ранньої мобілізації, задовільної функції (ковзання) відновленого сухожилковом'язового апарату майже неможливо досягнути при виконанні хірургічної реконструкції сухожилків та м'язів в межах основної рани [11]. Альтернативній методиці відновлення втрачених рухів, транспозиції сухожилків та м'язів притаманна основна функціональна перевага - усунення контакту переміщеного сухожилку чи м’яза із зоною основної травми i, як наслідок, значне зниження ризику тенодезування [11]. Ось чому транспозиція сухожилків та м'язів, навіть за наявності технічної можливості виконати хірургічну реконструкцію ушкодженого сухожилкові-м'язового апарату, стає вимушеною процедурою, направленою на досягнення найліпшого функціонального результату. Основним показанням до використання даної методики є заміщення функції незалежних м'язів, найчастіше м'язів, що забезпечують функції першого пальця. Використання функціонально незалежних м'язів-донорів є обов'язковою умовою вказаної вище техніки.

Мета роботи: оцінити ефективність "вимушених” транспозицій при проксимальних поєднаних ушкодженнях нервових та сухожилково-м'язових структур на передній поверхні передпліччя через призму відновлення основних захватів кисті.

Матеріали і методи. Проведено ретроспективний аналіз результатів реконструктивних втручань у 9 пацієнтів із наслідками проксимальних поєднаних ушкоджень довгих нервів та сухожилко-м'язового апарату передньої поверхні передпліччя, що проходили лікування в ДУ “Інститут нейрохірургії ім. акад. А.П. Ромоданова НАМН України” протягом 2014-2017 рр.

Критеріями включення в дослідження були: 1) проксимальне відкрите ушкодження передньої поверхні передпліччя; 2) проксимальне ушкодження щонайменше одного довгого нерва передньої поверхні передпліччя; 3) збережена здатність до скорочення проксимальних кукс м'язів передньої поверхні передпліччя; 4) відсутність незворотних ішемічних змін м'язово-сухожилкового апарату переднього фаціального футляра передпліччя; 5) повна компенсація кровообігу в дистальних відділах верхньої кінцівки.

Характеристика пацієнтів, включених у дослідження. У дослідженні брали участь 6 чоловіків та 3 жінки віком від 9 до 70 років (середній вік 36,4 року). У 6 пацієнтів спостерігали відкриту травму передньої поверхні передпліччя недомінантної (лівої) верхньої кінцівки, у 3 випадках - домінантної (правої) верхньої кінцівки. В усіх пацієнтів травма сухожилково-м'язового апарату передньої поверхні передпліччя була поєднана із ушкодженням довгих нервів - 4 випадки лише серединного нерва (44 \%), 4 випадки поєднаного ушкодження серединного та ліктьового нервів (44 \%) та одного випадку поєднаного ушкодження серединного нерва та поверхневої гілки променевого нерва (12 \%). В 9 випадках ушкодження нервового та сухожилко-м'язового апарату супроводжувалось ушкодженням променевої артерії, а у 3 випадках ще й передньої міжкісткової артерії, що не вимагали проведення відновних судинних хірургічних втручань в ранньому чи пізньому періоді травми, не супроводжувалась незворотними ішемічними змінами м'язів переднього фаціального футляра передпліччя. Усім пацієнтам, котрі були включені в дослідження, реконструктивні втручання проводили за умов повної клінічної та інструментальної компенсації кровообігу в дистальних відділах верхньої кінцівці в середній термін 5 місяців (від 2 до 11 місяців) після відкритої травми передпліччя.

Клінічна неврологічна симптоматика на момент включення в дослідження у всіх 9 пацієнтів супроводжувалась повною втратою рухової та чутливої функції в дистальних (відносно рівня травми) відділах верхньої кінцівки: відсутністю функції усіх м’язів підвищення першого пальця, анестезією в автономній зоні іннервації серединного нерва; у 4 пацієнтів - додатково відсутністю функції внутрішніх м'язів кисті, анестезією в автономній зоні іннервації ліктьового нерва; в одного пацієнта - додатково ще анестезією в автономній зоні іннервації поверхневої гілки променевого нерва та вираженим невропатичним больовим синдромом. На момент включення в дослідження у жодного із пацієнтів не зареєстровано клінічних та інструментальних (ЕНМГ) ознак початкових чи триваючих регенераційних процесів - ушкодження відповідало 5 класу ушкодження відповідних нервів за Sunderland [12]. 
В усіх пацієнтів ушкодження м'язово-сухожилкового апарату в проксимальних відділах передпліччя супроводжувалась різким обмеженням активних рухів, повною втратою ізольованих та незалежних рухів в окремих п'ясно-фалангових та міжфалангових суглобах, із клінічним збереженням активної скоротливої здатності проксимальних кукс ушкоджених м'язів.

Характеристика хірургічних втручань на нервових структурах у пацієнтів включених в дослідження
У 3 із 4 пацієнтів із ушкодженням лише серединного нерва в структурі травми реконструктивне втручання полягало в виконанні автонейропластики литковим нервом (табл. 1). Середній розмір дефекту серединного нерва становив 5,5 см (від 4 до 6 см). Середня кількість автотрансплантатів литкового нерва, котра була використана для виповнення усього поперечного січення проксимальної та дистальної кукс нервового стовбура, становила 4 шт. (рис. 1).

Таблиця 1. Характеристика реконструктивних втручань у пацієнтів на нервових структурах, сухожилково-м'язовому апараті

\begin{tabular}{|c|c|c|c|c|c|c|c|}
\hline $\begin{array}{c}\text { Пацієнт, } \\
\text { дата } \\
\text { операції }\end{array}$ & Стать & $\begin{array}{l}\text { Ушкодження } \\
\text { нерва/нервів }\end{array}$ & $\begin{array}{c}\text { Вид } \\
\text { реконструкції } \\
\text { нерва/нервів }\end{array}$ & $\begin{array}{c}\text { Ушкодження } \\
\text { FPL }\end{array}$ & $\begin{array}{c}\text { Ушкодження } \\
\text { FDP2-3 }\end{array}$ & $\begin{array}{c}\text { Донори для } \\
\text { вимушеної } \\
\text { транспозиції } \\
\text { для FPL }\end{array}$ & $\begin{array}{c}\text { Донори для } \\
\text { вимушеної } \\
\text { транспозиції } \\
\text { для FDP2-3 }\end{array}$ \\
\hline $\begin{array}{c}\text { № } 1, \\
27.05 .2014\end{array}$ & ч & MN;UN & $\begin{array}{c}\text { невроліз; } \\
\text { аутологічна } \\
\text { пластика }\end{array}$ & $\mathrm{Hi}$ & так & - & FDS4-5 \\
\hline $\begin{array}{c}\text { № 2, } \\
\text { 23.12.2014 }\end{array}$ & ч & MN;UN & $\begin{array}{c}\text { аутологічна } \\
\text { пластика }\end{array}$ & $\mathrm{Hi}$ & так & - & м'язи \\
\hline $\begin{array}{c}\text { № 3, } \\
\text { 19.03.2015 }\end{array}$ & 4 & $\mathrm{MN}$ & $\begin{array}{c}\text { аутологічна } \\
\text { пластика }\end{array}$ & так & так & FDS4 & FDP3 \\
\hline $\begin{array}{c}\text { № 4, } \\
\text { 7.06.2016 }\end{array}$ & ч & MN;RSRN & $\begin{array}{c}\text { аутологічна } \\
\text { пластика }\end{array}$ & так & ні & FCR & - \\
\hline $\begin{array}{c}\text { № 5, } \\
\text { 2.08.2017 }\end{array}$ & ж & $\mathrm{MN}$ & Шов & Hi & так & - & FDS4 \\
\hline $\begin{array}{c}\text { № 6, } \\
\text { 9.08.2017 }\end{array}$ & Ж & MN;UN & $\begin{array}{c}\text { аутологічна } \\
\text { пластика }\end{array}$ & так & так & ECRL & PT \\
\hline $\begin{array}{c}\text { № 7, } \\
\text { 9.10.2017 }\end{array}$ & ч & MN;UN & $\begin{array}{c}\text { аутологічна } \\
\text { пластика }\end{array}$ & $\mathrm{Hi}$ & так & - & м'язи \\
\hline $\begin{array}{c}\text { № 8, } \\
\text { 23.10.2017 }\end{array}$ & ж & $\mathrm{MN}$ & $\begin{array}{c}\text { аутологічна } \\
\text { пластика }\end{array}$ & так & $\mathrm{Hi}$ & FDS2 & - \\
\hline $\begin{array}{c}\text { № 9, } \\
\text { 25.10.2017 }\end{array}$ & Ч & $\mathrm{MN}$ & невроліз & Hi & так & FDS4 & - \\
\hline
\end{tabular}

Примітки: MN - серединний нерв, UN - ліктьовий нерв, RSRN - поверхнева гілка променевого нерва, FPL - довгий згинач 1 пальця, FDP - глибокі згиначі пальців, де “цифра” відповідає порядковому номеру пальця, FCR - променевий згинач кисті, FDS - поверхневі згиначі пальців, де “цифра” відповідає порядковому номеру пальця, ECRL - довгий променевий розгинач кисті, РТ - круглий пронатор передпліччя, “м’язи” - анатомічно не ідентифіковані черевця м’язів на передній поверхні передпліччя із збереженим функціональним статусом.

В одного пацієнта (див. табл. 1) із ушкодженням лише серединного нерва в структурі травми, реконструктивне втручання полягало в виконанні нейрорафії нервового стовбура (рис. 2).

У 3 із 4 пацієнтів із ушкодженням серединного та ліктьового нервів у структурі травми реконструктивне втручання полягало в виконанні автонейропластики обох нервових стовбурів литковим нервом (табл. 1). Середній розмір дефекту серединного нерва становив 5 см, ліктьового нерва 6,7 см (від 6 до 7 см) відповідно. Середня кількість автотрансплантатів литкового нерва, котра була використана для виповнення усього поперечного січення проксимальної та дистальної кукс нервових стовбурів, становила 4 шт. для серединного нерва та 2 шт. для ліктьового нерва (рис. 3). Слід зазначити, що реконструктивне втручання було спрямоване насамперед на відновлення функцій серединного нерва, відповідно, ліктьовий нерв відновлювали за “залишковим” принципом.

Ще у одного пацієнта із ушкодженням серединного та ліктьового нервів у структурі травми 


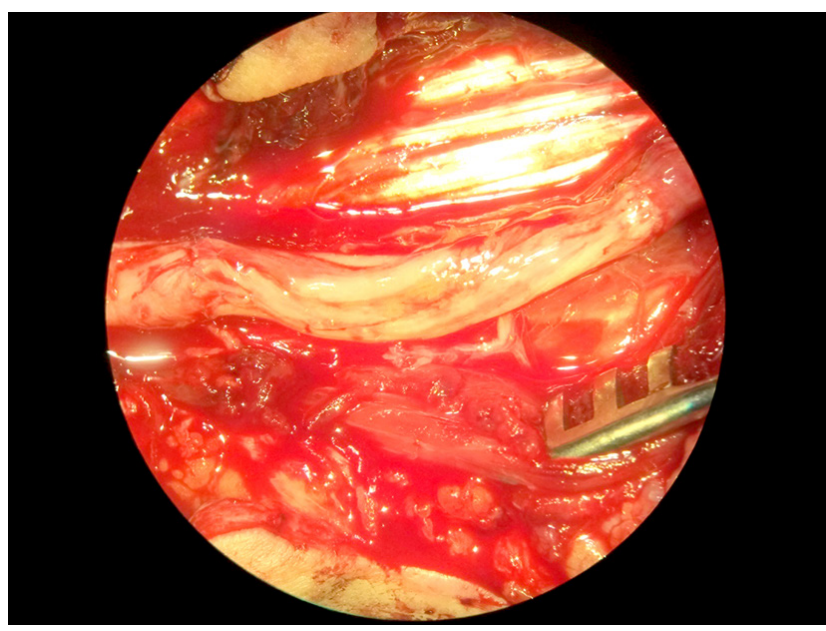

Рис. 1. Автонейропластика серединного нерва у в/3 передпліччя: інтраопераційна мікрофотографія під мікроскопічним збільшенням $\times 5$, дефект серединного нерва до 5 см, використано 5 автологічних трансплантатів із литкового нерва, перекрито усе поперечне січення проксимальної кукси серединного нерва.

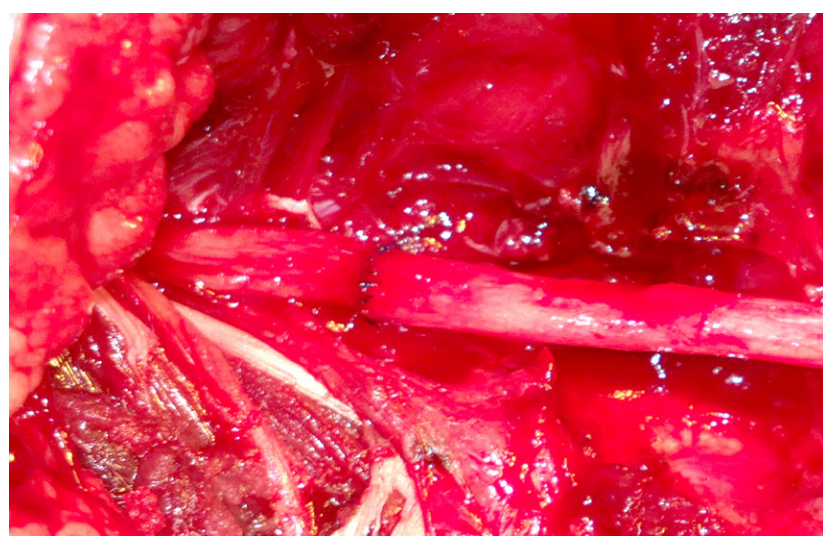

Рис. 2. Інтраопераційна макрофографія: нейрорафія серединного нерва в передпліччя при згинанні в ліктьовому суглобі під кутом $90^{\circ}$, адаптація кукс із дотриманням особливостей внутрішньостовбурової анатомії.

реконструктивне втручання полягало в виконанні автонейропластики ліктьового нерва та невролізу серединного нерва (табл. 1).

В одного пацієнта із ушкодженням серединного нерва та поверхневої гілки променевого нерва реконструктивне втручання полягало в виконанні автонейропластики обох нервових стовбурів (табл. 1).

Автонейропластику виконували під оптичним мікроскопічним збільшенням х8 атравматичним синтетичним нерозсмоктувальним шовним матеріалом 9/0 за UPS, адаптацію кукс нерва проводили фасцикулярними швами за кількістю аутотрансплантатів, необхідних для покриття усього поперечного січення проксимальної та дистальної кукс

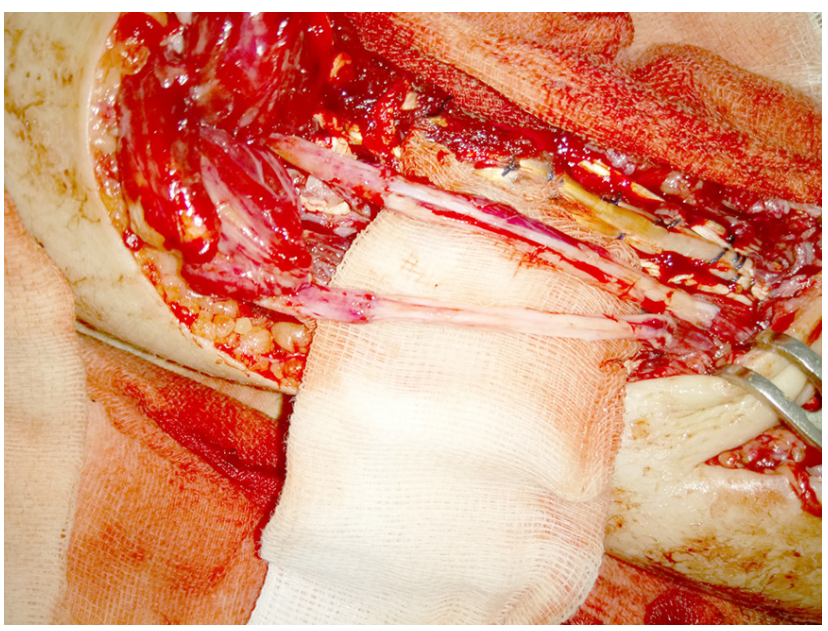

Рис. 3. Автонейропластика серединного та ліктьового нервів у с/3 передпліччя: інтраопераційна мікрофотографія; дефект серединного нерва до 5 см, використано 4 автологічні трансплантати із литкового нерва; дефект ліктьового нерва до 6 см, використано 3 автологічні трансплантати із литкового нерва.

нервів-реципієнтів із урахуванням особливостей внутрішньостовбурової архітектури серединного нерва. Нейрорафію виконували під оптичним мікроскопічним збільшенням х5 атравматичним синтетичним нерозсмоктувальним шовним матеріалом 7/0 за UPS, адаптацію кукс нервів проводили епіендоневральними швами із урахуванням особливостей внутрішньостовбурової архітектури. Зшивання серединного нерва виконували при згинанні в ліктьовому суглобі під кутом $90^{\circ}$ та супінації передпліччя 25-30 . Обов’ язковою умовою була можливість розгинання в ліктьовому суглобі щонайменше на $30^{\circ}$ після виконання нейрорафії без суттєвого збільшення напруження в зоні адаптації кукс серединного нерва.

У пацієнтів після нейрорафія серединного нерва в післяопераційному періоді проводили жорстку іммобілізацію в ліктьовому суглобі протягом 3 тижнів в положенні згинання/супінації передпліччя наближеному до фізіологічного з наступним поступовим збільшенням амплітуди рухів у ліктьовому суглобі ще протягом чотирьох тижнів після припинення іммобілізації.

Характеристика хірургічних втручань на сухожилково-м'язовому апараті передньої поверхні передпліччя у пацієнтів, включених у дослідження

В усіх пацієнтів, включених в дослідження, поєднане ушкодження сухожилково-м'язового апарату передньої поверхні передпліччя супроводжувалось їх масивними дефектами, що насамперед зумовлене характером травми, безпосередньою дією травмуючого агента. Локалізація ушко- 
дження в усіх випадках відповідала зоні м'язовосухожилкового переходу із збереженням скоротливої здатності власне черевця м'язів - проксимальної кукси м'язово-сухожилкового апарату. Анатомічна ідентифікація м'язових складових окремих груп згиначів була вкрай тяжкою у зв'язку із післятравматичними змінами, порушенням анатомотопографічних співвідношень, руйнуванням власних фаціальних футлярів тощо. Відповідно, реконструкція ушкодженого м'язово-сухожилкового апарату виключала можливість відновлення незалежного та індивідуального функціонування кожного із згиначів передньої поверхні передпліччя.

Основним завданням реконструкції сухожилково-м'язового апарату було відновлення незалежної функції довгого згинача 1 пальця, глибоких згиначів 2 та 3 пальців для забезпечення повноцінного функціонування чотирьох найбільш розповсюджених у щоденному вжитку захватів кисті.

Усім хворим одномоментно із реконструкцією нервових стовбурів виконано “вимушені” транспозиції м'язів для забезпечення виконання вказаної вище обов'язкової функціональної умови (табл. 1).

У 5 пацієнтів, включених у дослідження, реконструкція незалежної ізольованої функції згинання в дистальному міжфаланговому суглобі 1 пальця була досягнута шляхом “вимушеної” транспозиції збережених поверхневих згиначів пальців (4 пальця у двох випадках та 2 пальця в одному випадку), променевого згинача кисті та довгого променевого розгинача кисті.

У 6 пацієнтів, включених у дослідження (табл. 1), реконструкція незалежної ізольованої функції глибоких згиначів 2 та 3 пальців була досягнута шляхом “вимушеної” транспозиції збережених поверхневих згиначів пальців (4 та 5 пальців у двох випадках), тенопексії сухожилка глибокого згинача 3 пальця до сухожилка глибокого згинача 2 пальця (1 випадок), круглого пронатора передпліччя (1 випадок), анатомічно не ідентифікованих черевець м'язів на передній поверхні передпліччя із збереженим функціональним статусом (в 2 випадках).

У 2 пацієнтів спостерігали втрату незалежної ізольованої функції як глибоких згиначів 2 та 3 пальців, так і згинання в дистальному міжфаланговому суглобі 1 пальця (табл.1).

Обов'язковими умовами вибору м'язового “донора” для проведення вимушеної транспозиції були наявність інтактних фасціальних футлярів м'язівдонорів у межах передпліччя, можливість виконання анастомозу між донором та акцептором в ін- тактних тканинах передпліччя (задовольняє базові принципи транспозиції сухожилків). Формування анастомозу проводили із використанням обвивного сухожилкового шва чи шва за типом “fish-mouth" атравматичним синтетичним нерозсмоктуючим шовним матеріалом 2/0 чи 3/0 за UPS. У випадку використання як донорів анатомічно неідентифікованих черевець м'язів із збереженим функціональним статусом, подолання дефекту тканин сухожилкового м’язового апарату забезпечували автологічною сухожилковою пластикою.

У всіх пацієнтів після виконання “вимушеної” транспозиції м'язів в післяопераційному періоді проводили іммобілізацію протягом 3 тижнів з наданням дистально розташованим суглобам наближеного до фізіологічного положення. Ранню активну мобілізацію переміщених м'язів проводили лише протягом 1-3 днів після хірургічного втручання.

Усі хворі отримували стандартну протизапальну, протибольову терапію відповідно до вимог перебігу післяопераційного періоду.

Результати проведених реконструктивних втручань проводили за допомогою детального клініко-неврологічного та електрофізіологічного обстеження за стандартною методикою у Відділі функціональної діагностики ДУ “Інститут нейрохірургії ім. акад. А. П. Ромоданова НАМН України”. Перше оцінювання результатів реконструктивних втручань проводилась в індивідуальному порядку для кожного пацієнта включеного в дослідження (без відсутності чітких часових інтервалів обстеження) в строки, що щонайменше на два місяці випереджали передбачувані строки регенерації. 3 наступними (другим) обов’язковим оцінюванням результатів у передбачувані строки регенерації. Наступне оцінювання виконували при наступному зверненні хворого та до моменту відсутності суттєвого прогресу у відновленні втрачених неврологічних функцій (саме вони були використані при аналізі результатів дослідження). 3 метою надання ступеня відновлення неврологічних функцій кількісних характеристик використовували такі шкали: 1) MRC Scale - для оцінки ступеня відновлення рухової сфери; 2) класифікація порушення (відновлення) чутливості за Seddon.

Функціональний аспект регенерації оцінювали на основі відновлення 4 найбільш розповсюджених захватів кисті під час щоденної активності [13]. Додатково кожен хворий проводив власну оцінку відновлених функцій верхньої кінцівки за Brief Michigan Hand Questionnaire (MBHQ) [14].

Невелика кількість хворих, включених в дослідження, не дозволила провести будь-якого значущого статистичного аналізу. 
Дослідження виконано із дотриманням усіх вимог Етичного комітету ДУ “Інститут нейрохірургії ім. акад. А. П. Ромоданова НАМН України”, Національного комітету з медичної етики України, Гельсинської Декларації 1964p. (усіх наступних доповнень та змін); добровільну інформовану згоду отримали від усіх учасників, включених у дане дослідження.

Результати досліджень та їх обговорення. У всіх 4 хворих із ізольованим ушкодженням серединного нерва в структурі поєднаної травми відновлення чутливості в автономній зоні іннервації склала в середньому 3,75 за шкалою Seddon. До того ж, у трьох випадках після виконання автонейропластики серединного нерва відновлення чутливості становило 4 за шкалою Seddon.

У 4 пацієнтів із ушкодженням серединного та ліктьового нервів у структурі поєднаної травми відновлення чутливості в автономній зоні іннер- вації серединного нерва дорівнювала 3 за шкалою Seddon. Відновлення чутливості в автономній зоні іннервації ліктьового нерва становила в середньому 2 за шкалою Seddon (від 1 до 3).

У жодного пацієнта ми не спостерігали відсутності відновлення м'язів підвищення 1 пальця. Слід зазначити, що в 2 пацієнтів (у одного пацієнта після виконання невролізу, ще у одного після виконання зшивання серединного нерва) із задовільним відновленням м'язів підвищення 1 пальця, протиставлення власне 1 пальця частково втратила автономність несправжнє синкінетичне напруження м'язів із згиначами пальців. Дану особливість можна пояснити крайнім проявом феномена “гетеротопної” реіннервації. У одного із вказаних вище пацієнтів несправжня співдружня функція м'язів підвищення 1 пальця та згиначів пальців домінантної (правої) верхньої кінцівки вимагала проведення на більш пізніх етапах корегуючого ортопедичного втручання - пацієнту виконали транспозицію за Bunnel (рис. 4).
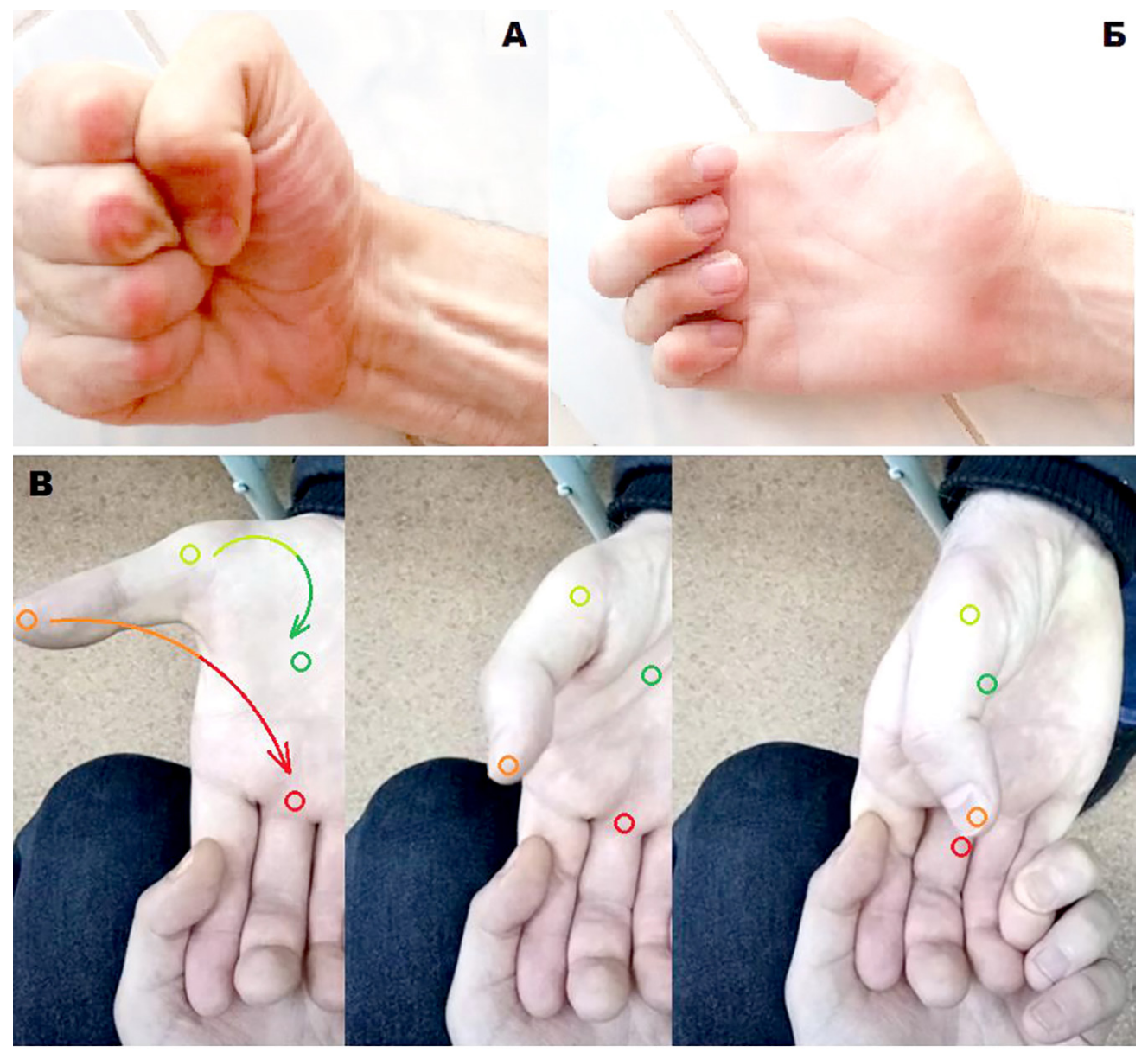

Рис. 4. Відновлення автономної функції протиставлення 1 пальця за рахунок транспозиції за Bunnel: A - протиставлення першого пальця асоційоване із напруженням згиначів пальців; Б - виражена деформація за типом “мавп’ячої” кисті при відсутності функції та гіпотрофії м’язів підвищення першого пальця, 16 місяців після комбінованої реконструкції серединного нерва та сухожилково-м’язового апарату; В - відновлення незалежного протиставлення першого пальця через 9 місяців після транспозиції за Bunnel. 
У всіх 4 пацієнтів із ушкодженням серединного та ліктьового нервів в структурі травми ми спостерігали незадовільне відновлення "внутрішніх” м'язів кисті, іннервація яких забезпечується ліктьовим нервом. Зокрема, в усіх пацієнтів в пізньому періоді після реконструкції (при наявності електрофізіологічних та клінічних ознак регенерації без подальшої позитивної динаміки) ми спостерігали деформацію за типом "рука проповідника”, виражену гіпотрофія міжп’ясних м’язів, м'язів, що приводять перший палець.

У п’яти пацієнтів після проведення вимушених транспозицій досягнуто незалежної дискретної функції довгого згинача 1 пальця. У шести пацієнтів після проведення вимушених транспозицій досягнуто незалежної дискретної функції глибоких згиначів 2 та 3 пальців. Жоден із згаданих хворих не вимагав проведення тенолізу переміщених сухожилків, обсяг рухів у відповідних сегментах відповідав таким на інтактній кінцівці. Насамперед це було пов'язано із можливістю проведення ранньої реабілітації, раннього навантаження на знерухомлені сегменти без розвитку значного ризику виникнення неспроможності сухожилкових швів у ділянці анастомозування. По-друге, дотримання базових вимог до транспозиції сухожилків, зокрема відмежування зони “ковзання” переміщеного м'яза/сухожилка від основної рани, дозволило мінімізувати тенодезуючий ефект в ділянці “свіжої” хірургічної рани.

У всіх пацієнтів після проведення комплексної реконструкції нервових та сухожилком'язових структур вдалося досягнути відновлення поперечного долонного, діагонального долонного та щипкового захватів. У 4 пацієнтів (44 \% від усіх включених у дослідження та $100 \%$ із ушкодженням двох довгих нервів) відсутність відновлення ключового захвату була зумовлена відсутністю належної регенерації “внутрішніх" м’язів кисті, іннервацію яких забезпечує ліктьовий нерв (рис. 5).

Пацієнти, що були включені в дослідження, в середньому оцінювали відновлену функцію кінцівки в результаті проведених комплексних реконструктивних втручань як задовільну - 70,12 балів за MBHQ (від 43,75 до 89,6). Ми не спостерігали чіткої залежності зміни власного оцінювання відновлених функцій від сторони ураження домінантної чи недомінантної кінцівки. У одного пацієнта реконструктивне втручання, направлене на забезпечення незалежного протиставлення

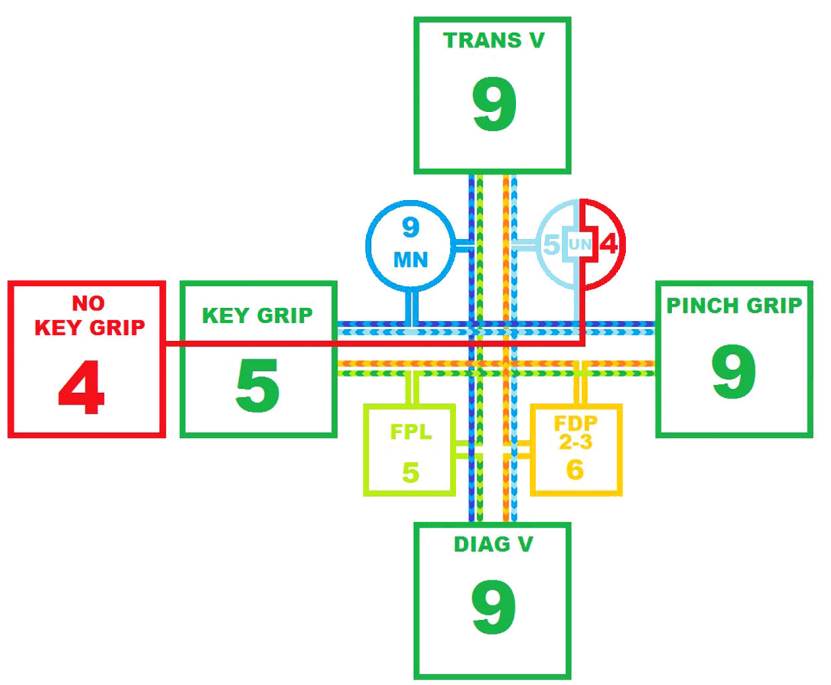

Рис. 5. Відновлення основних захватів верхньої кінцівки в результаті проведених комплексних реконструктивних втручань, роль нервових та сухожилково-м'язових структур в їх функціонуванні: MN - серединний нерв, протиставлення першого пальця; UN - ліктьовий нерв, приведення першого пальця; FPL - довгий м'яз, що згинає перший палець, згинання в дистальному міжфаланговому суглобі; FDP - м'язи глибокі згиначі пальців, де цифра відповідає порядковому номеру пальця; Key grip - ключовий захват; Pinch grip - щипковий захват; Diag V діагональний долонний захват; Trans V - поперечний долонний захват.

першого пальця (транспозиція за Bunnel), дозволило покращити функцію домінантної кінцівки 3 43,75 до 67,2 за MBHQ.

Висновки. 1. Вимушені транспозиції м'язів, за наявності поширених дефектів сухожилковом'язового апарату в проксимальних відділах передпліччя, здатні забезпечити ефективну та незалежну функцію згиначів 1-3 пальців.

2. Вимушені транспозиції м'язів, за наявності поширених дефектів сухожилково-м'язового апарату в проксимальних відділах передпліччя, здатні забезпечити ефективне відновлення щипкового, діагонального долонного, поперечного долонного захватів.

3. Відсутність ефективного відновлення ключового захвату кисті (до 20 \% функції кисті), незважаючи на можливість заміщення функції згиначів 1-3 пальців, відновлення щипкового, діагонального та поперечного долонних захватів (до 49 \% функції кисті) шляхом проведення вимушених транспозицій, зумовлена відсутністю ефективної регенерації ліктьового нерва, а саме “внутрішніх” м'язів кисті. 


\section{ОРИГІНАЛЬНІ ДОСЛІДЖЕННЯ}

\section{СПИСОК ЛІТЕРАТУРИ}

1. Robinson L. R. Traumatic injury to peripheral nerves / L. R. Robinson // Muscle Nerve. - 2000. - Vol. 23. - P. 863-873; 2. Vascular trauma of the upper limb and associated nerve injuries / A. D. Shaw, A. A. Milne, J. Christie [et al.] // Injury. 1995. - Vol. 26 (8). - P. 515-518.

3. Hull J. B. Management of gunshot fractures of the extremities / J. B. Hull // The Journal of Trauma: Injury, Infection, and Critical Care [Internet]. Ovid Technologies (Wolters Kluwer Health). 1996. - Vol. 40 (Supplement). - P. 193S-197S. Available from: http://dx.doi.org/10.1097/00005373-199603001-00043.

4. Median and ulnar nerve injuries: a meta-analysis of predictors of motor and sensory recovery after modern microsurgical nerve repair / A. C. Ruijs, J. B. Jaquet, S. Kalmijn [et al.] // Plast. Reconstr. Surg. - 2005. - Vol. 116 (2). - P. 484-494.

5. Recovery of skeletal muscle after laceration and repair / W. E. Garrett, A. V. Seaber, J. Boswick [et al.] // The Journal of Hand Surgery [Internet]. Elsevier BV. - 1984. - Vol. 9 (5). - P. 683-692. Available from: http://dx.doi.org/10.1016/s03635023(84)80014-3.

6. Total rupture of pectoralis major muscle in athletes / S. Orava, A. Sorasto, K. Aalto, H. Kvist // International Journal of Sports Medicine [Internet]. Georg Thieme Verlag KG. - 1984. - Vol. 05 (05). - P. 272-274. Available from: http://dx.doi. org/10.1055/s-2008-1025919;

7. Chekofsky K. M. A Method of repair of late quadriceps rupture / K. M. Chekofsky, C. R. Spero, W. N. Scott // Clinical Orthopaedics and Related Research [Internet]. Ovid Technologies (Wolters Kluwer Health). - 1980. - No. 147. - P. 190-191. Available from: http://dx.doi.org/10.1097/00003086-19800300000033;

8. Surgical repair of muscle laceration:biomechanical properties at 6 years follow-up / F. Oliva, A. G. Via, O. Kiritsi [et al.] // Muscles Ligaments Tendons. - 2014. - Vol. 24 (3). - P. 313-317. 9. Suturing of lacerations of skeletal muscle / J. F. Kragh, S. J. Svoboda, J. C. Wenke [et al.] // The Journal of Bone and Joint Surgery British volume [Internet]. British Editorial Society of Bone \& Joint Surgery. - 2005. - Vol. 87-B (9). P. 1303-1305. Available from: http://dx.doi.org/10.1302/0301620x.87b9.15728.

10. Epimysium and perimysium in suturing in skeletal muscle lacerations / J. F. Kragh, S. J. Svoboda, J. C. Wenke [et al.] // The Journal of Trauma: Injury, Infection, and Critical Care [Internet]. Ovid Technologies (Wolters Kluwer Health). - 2005. - Vol. 59 (1). - P. 209-212. Available from: http://dx.doi.org/10.1097/01. ta.0000171530.11588.70

11. Beasley R. W. 20 Tendon transfers. Beasley’s surgery of the hand [Internet] / R. W. Beasley; ed. - Georg Thieme Verlag; 2003. Available from: http://dx.doi.org/10.1055/b-0034-52157;

12. Sunderland S. A classification of peripheral nerve injuries producing loss of function / S. Sunderland // Brain. - 1951. Vol. 74 (4). - P. 491-516. doi:10.1093/brain/74.4.491;

13. Sollerman C. Sollerman hand function test: A standardised method and its use in tetraplegic patients / C. Sollerman, A. Ejeskär // Scandinavian Journal of Plastic and Reconstructive Surgery and Hand Surgery. - 1995. - Vol. 29 (2). - P. 167-176. doi:10.3109/02844319509034334;

14. Development of a Brief, 12-Item Version of the Michigan Hand Questionnaire / J. F. Waljee, H. M. Kim, P. B. Burns, K. C. Chung // Plastic and Reconstructive Surgery. - 2011. - Vol. 128 (1). - P. 208220. doi:10.1097/prs.0b013e318218fc51.APA
15. Robinson L. R. Traumatic injury to peripheral nerves / L. R. Robinson // Muscle Nerve. - 2000.

16. Vascular trauma of the upper limb and associated nerve injuries / A. D. Shaw, A. A. Milne, J. Christie [et al.] // Injury. $-1995$.

17. Hull J. B. Management of gunshot fractures of the extremities / J. B. Hull // The Journal of Trauma: Injury, Infection, and Critical Care [Internet]. Ovid Technologies (Wolters Kluwer Health). - 1996. Available from: http://dx.doi.org/10.1097/00005373199603001-00043

18. Median and ulnar nerve injuries: a meta-analysis of predictors of motor and sensory recovery after modern microsurgical nerve repair / A. C. Ruijs, J. B. Jaquet, S. Kalmijn [et al.] // Plast. Reconstr. Surg. - 2005.

19. Recovery of skeletal muscle after laceration and repair / W. E. Garrett, A. V. Seaber, J. Boswick [et al.] // The Journal of Hand Surgery. - 1984. [Internet]. http://dx.doi.org/10.1016/ s0363-5023(84)80014-3;

20. Total rupture of pectoralis major muscle in athletes / S. Orava, A. Sorasto, K. Aalto, H. Kvist // International Journal of Sports Medicine [Internet]. Georg Thieme Verlag KG. - 1984. Available from: http://dx.doi.org/10.1055/s-2008-1025919;

21. Chekofsky K. M. A method of repair of late quadriceps rupture / K. M. Chekofsky, C. R. Spero, W. N. Scott // Clinical Orthopaedics and Related Research [Internet]. Ovid Technologies (Wolters Kluwer Health). - 1980. - No. 147. - P.190 - 191. Available from: http://dx.doi.org/10.1097/00003086-19800300000033;

22. Surgical repair of muscle laceration:biomechanical properties at 6 years follow-up / F. Oliva, A. G. Via, O. Kiritsi [et al.] // Muscles Ligaments Tendons. - 2014. - Vol. 24 (3). - P. 313317 ;

23. Suturing of lacerations of skeletal muscle / J. F. Kragh, S. J. Svoboda, J. C. Wenke [et al.] // The Journal of Bone and Joint Surgery British volume [Internet]. British Editorial Society of Bone \& Joint Surgery. - 2005. - Vol. 87-B (9). P. 1303-1305. Available from: http://dx.doi.org/10.1302/0301620x.87b9.15728;

24. Epimysium and perimysium in suturing in skeletal muscle lacerations / J. F. Kragh, S. J. Svoboda, J. C. Wenke [et al.] // The Journal of Trauma: Injury, Infection, and Critical Care [Internet]. Ovid Technologies (Wolters Kluwer Health). - 2005. - Vol. 59 (1). - P. 209-212. Available from: http://dx.doi.org/10.1097/01. ta.0000171530.11588.70;

25. Beasley R. W. 20 Tendon Transfers. Beasley's Surgery of the Hand [Internet] / R. W. Beasley; ed. - Georg Thieme Verlag; 2003; Available from: http://dx.doi.org/10.1055/b-0034-52157; 26. Sunderland S. A classification of peripheral nerve injuries producing loss of function / S. Sunderland // Brain. - Vol. 74 (4). - P. 91-516. doi:10.1093/brain/74.4.491;

27. Sollerman C. Sollerman hand function test: A standardised method and its use in tetraplegic patients / C. Sollerman, A. Ejeskär // Scandinavian Journal of Plastic and Reconstructive Surgery and Hand Surgery. - 1995. - Vol. 29 (2). - P. 167-176. doi:10.3109/02844319509034334;

28. Development of a brief, 12-item version of the Michigan Hand Questionnaire / J. F. Waljee, H. M. Kim, P. B. Burns, K. C. Chung // Plastic and Reconstructive Surgery. - 2011. Vol. 128 (1). - P. 208-220. doi:10.1097/prs.0b013e318218fc51. 


\section{REFERENCES}

1. Robinson, L.R. (2000). Traumatic injury to peripheral nerves. Muscle Nerve, 23, 863-873;

2. Shaw, A.D., Milne, A.A., Christie, J., Jenkins, A.M., Murie, J.A., \& Ruckley, C.V. (1995). Vascular trauma of the upper limb and associated nerve injuries. Injury, 26 (8), 515-518; 3. Hull, J.B. (1996). Management of gunshot fractures of the extremities. The Journal of Trauma: Injury, Infection, and Critical Care [Internet]. Ovid Technologies (Wolters Kluwer Health), 193S-197S. Retrieved from: http://dx.doi.org/10.1097/00005373199603001-00043;

4. Ruijs, A.C., Jaquet, J.B., Kalmijn, S., Giele, H., \& Hovius, S.E. (2005). Median and ulnar nerve injuries: a meta-analysis of predictors of motor and sensory recovery after modern microsurgical nerve repair. Plast. Reconstr. Surg., 116 (2), 484-494;

5. Garrett, W.E., Seaber, A.V., Boswick, J., Urbaniak, J.R., \& Goldner, J.L. (1984). Recovery of skeletal muscle after laceration and repair. The Journal of Hand Surgery [Internet]. Elsevier BV, 9 (5), 683-692. - Retrieved from: http://dx.doi.org/10.1016/ s0363-5023(84)80014-3;

6. Orava, S., Sorasto, A., Aalto, K., \& Kvist, H. (1984). Total rupture of pectoralis major muscle in athletes. International Journal of Sports Medicine [Internet]. Georg Thieme Verlag KG, 05 (05), 272-274. Available from: http://dx.doi. org/10.1055/s-2008-1025919;

7. Chekofsky, K.M., Spero, C.R., \& Scott, W.N. (1980). A method of repair of late quadriceps rupture. Clinical Orthopaedics and Related Research [Internet]. Ovid Technologies (Wolters Kluwer Health), (147), 190-191. Available from: http://dx.doi. org/10.1097/00003086-198003000-00033;

8. Oliva, F., Via, A.G., Kiritsi, O., Foti, C., \& Maffulli, N. (2014). Surgical repair of muscle laceration:biomechanical properties at 6 years follow-up. Muscles Ligaments Tendons, 24 (3), 313-317; 9. Kragh, J.F., Svoboda, S.J., Wenke, J.C., Ward, J.A., \& Walters, T.J. (2005). Suturing of lacerations of skeletal muscle. The Journal of Bone and Joint Surgery British volume [Internet]. British Editorial Society of Bone \& Joint Surgery, 87-B (9), 1303-1305. Retrieved from: http://dx.doi.org/10.1302/0301620x.87b9.15728;

10. Kragh, J.F., Svoboda, S.J., Wenke, J.C., Ward, J.A., \& Walters, T.J. (2005). Epimysium and perimysium in suturing in skeletal muscle lacerations. The Journal of Trauma: Injury, Infection, and Critical Care [Internet]. Ovid Technologies (Wolters Kluwer Health), 59 (1), 209-212. Retrieved from: http:// dx.doi.org/10.1097/01.ta.0000171530.11588.70;

11. Beasley, R.W. (Ed.). (2003). 20 Tendon Transfers. Beasley's Surgery of the Hand [Internet]. Georg Thieme Verlag. Retrieved from: http://dx.doi.org/10.1055/b-0034-52157;

12. Sunderland, S. (1951). A classification of peripheral nerve injuries producing loss of function. Brain, 74 (4), 491-516. doi:10.1093/brain/74.4.491;

13. Sollerman, C., \& Ejeskär, A. (1995). Sollerman hand function test: A standardised method and its use in tetraplegic patients. Scandinavian Journal of Plastic and Reconstructive Surgery and Hand Surgery, 29 (2), 167-176. doi:10.3109/02844319509034334; 14. Waljee, J.F., Kim, H.M., Burns, P.B., \& Chung, K.C. (2011). Development of a Brief, 12-Item Version of the Michigan Hand Questionnaire. Plastic and Reconstructive Surgery, 128 (1), 208-
220. doi:10.1097/prs.0b013e318218fc51. APA

15. Robinson, L.R. (2000). Traumatic injury to peripheral nerves. Muscle Nerve.

16. Shaw, A.D., Milne, A.A., Christie, J., Jenkins, A.M., Murie, J.A., Ruckley, C.V. (1995). Vascular trauma of the upper limb and associated nerve injuries. Injury.

17. Hull, J.B. (1996). Management of gunshot fractures of the extremities. The Journal of Trauma: Injury, Infection, and Critical Care [Internet]. Ovid Technologies (Wolters Kluwer Health). Retrieved from: http://dx.doi.org/10.1097/00005373-19960300100043

18. Ruijs, A.C., Jaquet, J.B., Kalmijn, S., Giele, H., \& Hovius, S.E. (2005). Median and ulnar nerve injuries: a metaanalysis of predictors of motor and sensory recovery after modern microsurgical nerve repair. Plast. Reconstr. Surg.

19. Garrett, W.E., Seaber, A.V., Boswick, J., Urbaniak, J.R., \& Goldner, J.L. (1984). Recovery of skeletal muscle after laceration and repair. The Journal of Hand Surgery [Internet]. http://dx.doi. org/10.1016/s0363-5023(84)80014-3;

20. Orava, S., Sorasto, A., Aalto, K., \& Kvist, H. (1984). Total rupture of pectoralis major muscle in athletes. International Journal of Sports Medicine [Internet]. Georg Thieme Verlag KG. - Retrieved from: http://dx.doi.org/10.1055/s-2008-1025919; 21. Chekofsky, K.M., Spero, C.R., \& Scott, W.N. (1980). A method of repair of late quadriceps rupture. Clinical Orthopaedics and Related Research [Internet]. Ovid Technologies (Wolters Kluwer Health). (147), 190-191. Retrieved from: http://dx.doi. org/10.1097/00003086-198003000-00033;

22. Oliva, F., Via, A.G., Kiritsi, O., Foti, C., \& Maffulli, N. (2014). Surgical repair of muscle laceration:biomechanical properties at 6 years follow-up. Muscles Ligaments Tendons, 24 (3), 313-317; 23. Kragh, J.F., Svoboda, S.J., Wenke, J.C., Ward, J.A., \& Walters, T.J. (2005). Suturing of lacerations of skeletal muscle. The Journal of Bone and Joint Surgery British volume [Internet]. British Editorial Society of Bone \& Joint Surgery, 87-B (9), 1303-1305. Retrieved from: http://dx.doi.org/10.1302/0301620x.87b9.15728;

24. Kragh, J.F., Svoboda, S.J., Wenke, J.C., Ward, J.A., \& Walters, T.J. (2005). Epimysium and perimysium in suturing in skeletal muscle lacerations. The Journal of Trauma: Injury, Infection, and Critical Care [Internet]. Ovid Technologies (Wolters Kluwer Health), 59 (1), 209-212. Retrieved from: http:// dx.doi.org/10.1097/01.ta.0000171530.11588.70;

25. Beasley, R.W. (Ed.). 20 Tendon Transfers. Beasley's Surgery of the Hand [Internet]. Georg Thieme Verlag. Retrieved from: http://dx.doi.org/10.1055/b-0034-52157;

26. Sunderland, S. (1951). A classification of peripheral nerve injuries producing loss of function. Brain, 74 (4), 491-516. doi:10.1093/brain/74.4.491;

27. Sollerman, C., \& Ejeskär, A. (1995). Sollerman hand function test: A standardised method and its use in tetraplegic patients. Scandinavian Journal of Plastic and Reconstructive Surgery and Hand Surgery, 29 (2), 167-176. doi:10.3109/02844319509034334; 28. Waljee, J.F., Kim, H.M., Burns, P.B., \& Chung, K.C. (2011). Development of a Brief, 12-Item Version of the Michigan Hand Questionnaire. Plastic and Reconstructive Surgery, 128 (1), 208220. doi:10.1097/prs.0b013e318218fc51. 


\title{
COMBINED INJURIES OF THE NERVE AND TENDON MUSCLE STRUCTURES ON THE FOREARM, ACCOMPANIED BY THEIR SIGNIFICANT DEFECTS: THE ROLE OF FORCED MUSCLES TRANSPOSITION IN THE RESTORATION OF THE BASIC FUNCTIONS OF THE HAND
}

\begin{abstract}
The aim of the work: to evaluate the functional influence of the tendon transfers on recovery of the principal hand grips and pinches at simultaneous lesions of the nerves and musculo-tendineous apparatus in the upper forearm.

Materials and Methods. The study presents a retrospective analysis of the surgical reconstruction of the nerves and musculo-tendineous apparatus in the upper forearm in 9 patients (6 men and 3 women) with mean age of 36.4 years. 4 patients enrolled into the study showed single median nerve lesion, 4 patients showed median and ulnar nerve lesions, 1 patient showed median and superficial radial nerve lesions. Mean post injury term was 5 months. Surgical reconstruction of the nerves included: autologous nerve grafting (6 cases), neurolysis (2 cases), suture of the nerve (1 case). In five cases tendon transfers were aimed to restore independent function of the flexor pollicis longus, in six cases - to restore independent function of the profound flexors of the index and middle finger. Outcomes evaluation included the quantification of the muscles strength on MRC Scale, sensitivity recovery on Seddon's Scale, recovery of 4 principal hand grips and pinches, Brief Michigan Hand Questionnaire (BMHQ).

Results and Discussion. Four patients with single nerve injury to the median nerve received mean sensation value 3.75 on Seddon's Scale. Four patients with the injury to the median and ulnar nerve received mean sensation value 3 and 2 on Seddon's Scale respectively. Ineffective recovery to the thenar muscles of the hand in 2 patients required Bunnel tendon transfer in much later terms in order to restore proper thumb opposition. Four patients with the injury to the ulnar nerve showed poor recover of the intrinsic muscles of the hand. In five cases tendon transfers allowed us to restore independent functioning of the flexor pollicis longus, in six cases - independent functioning of profound index and middle finger flexors. All nine patients showed recovery of the transversal and diagonal volar grips, as well as pulp pinch. Four patients showed no recovery of the lateral pinch due to poor functioning of the intrinsic muscles of the hand (ulnar nerve). Mean MBHQ value was 70.12 points (from 43.75 up to 89.6).

Conclusions. Tendon transfers are able to restore effective and independent functioning of the thumb, index and middle finger flexors, effective recovery of the transversal and diagonal volar grips, as well as pulp pinch; loss of lateral pinch was determined by poor recovery of the intrinsic muscles of the hand, hence poor regeneration of the ulnar nerve at its proximal lesion.
\end{abstract}

Key words: injury; forearm; tendons; muscles; tendon transfer; median nerve; ulnar nerve; autologous nerve grafting.

И. Б. ТРЕТЬЯК, А. А. ГАЦКИЙ, И. В. КОВАЛЕНКО, А. И. ТРЕТЬЯКОВА

ГУ “Институт нейрохирургии имени академика А. П. Ромоданова НАМН Украины”

\section{СОЧЕТАННЫЕ ПОВРЕЖКДЕНИЯ НЕРВНЫХ И СУХОЖИЛЬНО-МЫШЕЧНЫХ СТРУКТУР НА ПРЕДПЛЕЧЬЕ, КОТОРЫЕ СОПРОВОЖДАЮТСЯ ИХ ЗНАЧИТЕЛЬНЫМИ ДЕФЕКТАМИ: РОЛЬ ВЫНУЖДЕННОЙ ТРАНСПОЗИЦИИ МЫШЩ В ВОЗОБНОВЛЕНИИ ОСНОВНЫХ ФУНКЦИЙ КИСТИ}

\begin{abstract}
Цель работы: оценить эффективность “вынужденных” транспозиций при повреждениях сухожильно-мышечных и нервных структур на восстановление основных захватов кисти.

Материалы и методы. Проведен ретроспективный анализ результатов реконструктивных вмешательств у 9 пациентов (6 мужчин и 3 женщины) в возрасте от 9 до 70 лет (средний возраст 36,4 года) с последствиями проксимальных сочетанных повреждений длинных нервов и сухожильно-мышечного аппарата передней поверхности предплечья. Травма сухожильномышечного аппарата была сопряжена с повреждением в 4 случаях срединного нерва, в 4 случаях срединного и локтевого нервов, в одном случае - срединного нерва и поверхностной ветви лучевого нерва. Срок, в который проводились реконструктивные вмешательства, составлял в среднем 5 месяцев (от 2 до 11 месяцев) после травмы. У 6 пациентов хирургическая реконструкция нервов заключалась в выполнении аутологической пластики, у 2 пациентов - невролиз, в одного пациента - шва нерва. В 5 случаях “вынужденная” транспозиция была выполнена с целью восстановления независимой функции длинного сгибателя 1 пальца, в 6 случаях - независимой функции глубоких сгибателей 2-3 пальцев. Восстановление неврологических функций оценивали по MRC Scale, классификации по Seddon, восстановлением 4 захватов кисти, собственной оценкой восстановленных функций по Brief Michigan Hand Questionnaire.

Результаты исследований и их обсуждение. Во всех 4 пациентов с повреждением только срединного нерва восстановление чувствительности составляло в среднем 3,75 по Seddon. У 4 пациентов с повреждением срединного и локтевого нервов восстановление чувствительности составляло в среднем 3 и 2 по Seddon соответственно. Неэффективное восстановление противопоставления первого пальца у 2 пациентов скорректировано транспозицией по Bunnel. У 4 пациентов с повреждением срединного и локтевого нервов мы наблюдали неудовлетворительное восстановление “внутренних" мышц кисти.

У 5 пациентов “вынужденные” транспозиции восстановили независимую функцию длинного сгибателя 1 пальца, у 6 пациентов - независимую функцию глубоких сгибателей 2-3 пальцев. В 9 пациентов комплексная хирургическая реконструкция возобновила функцию поперечного ладонного, диагонального ладонного и щипкового захватов. У 4 пациентов (44 \%) не достигнуто восстановления ключевого захвата, в связи с неудовлетворительным восстановлением “внутренних” мышц кисти (локтевой нерв). Средняя собственная оценка функции кисти с MBHQ отвечала удовлетворительной у 9 пациентов - 70,12 балла в среднем (от 43,75 до 89,6).
\end{abstract}

Ключевые слова: повреждение; предплечья; сухожилия; мышцы; транспозиция сухожилий; срединный нерв; локтевой нерв; аутологическая пластика. 